\title{
KECERDASAN EMOSIONAL MENINGKATKAN KREATIVITAS GURU DALAM MENGAJAR
}

\begin{abstract}
Akhmad Asyari*
Abstrak: Proses pembelajaran di kelas merupakan suatu interaksi yang melibatkan sikap dan daya kreatifitas antara guru dengan siswa dan suatu komunikasi timbal balik yang berlangsung dalam suasana eduakatif untuk pencapaian tujuan belajar. Faktor yang paling signifikan yang menyebabkan ketidakpuasan di sekolah adalah kegagalan, dan putusnya jalinan komunikasi dua arah yang melibatkan aspek kecerdasan sosial emosional. Guru dalam proses membelajarkan dituntut untuk professional dalam bersikap dan kreatif dalam membentuk pola intraksi yang dapat mendorong siswa untuk belajar, sedangkan pembentukan sikap dan daya kreatifitas membutuhkan kecerdasan emosi yang dapat mempengaruhi pikiran, perasaan, respon, dan memanipulasi informasi dalam menjalin hubungan yang harmonis dengan siswa.
\end{abstract}

Kata kunci: kecerdasan emosional, sikap, kreatifitas, guru, membelajarkan

\section{Pendahuluan}

Dentingnya peranan pendidikan dalam menghadapi perubahan dalam era globalisasi, maka pemerintah mengeluarkan UU L No. 20 Tahun 2003 Tentang Sistem Pendidikan Nasional dimana pendidikan diarahkan agar peserta didik secara aktif mengembangkan potensi dirinya untuk memiliki kekuatan spiritual keagamaan, pengendalian diri, kepribadian, kecerdasan, akhlak mulia, serta keterampilan yang diperlukan dirinya, masyarakat, bangsa dan negara (Depdiknas, 2003:1). Jika mengacu pada fungsi

*Jurusan PAI FITK IAIN Mataram. Email: asyari_smart@yahoo.com 
dan tujuan pendidikan nasional tersebut, terlihat jelas bahwa Undang-undang di atas menghendaki guru yang memiliki kecerdasan emosional kreatif, mempunyai sikap yang ajeg, mandiri dan mapan, sehingga dalam proses membelajarkan peserta didik, guru secara aktif mengembangkan potensi dirinya untuk memiliki kekuatan pengendalian diri, kepribadian, kecerdasan, akhlak mulia yang berimplikasi pada kualitas proses (quality process) pembelajaran, jaminan kualitas (quality insurance) produk pembelajaran serta kualitas output (quality produce) sebagai tujuan akhir pembelajaran. Tentunya hal ini akan dapat tercapai jika guru memiliki kompetensi kepribadian dimana kecerdasan emosional adalah aspek intern yang paling dominan.

Pendidikan merupakan proses tri-kutub, di mana guru, pelajar, dan kurikulum merupakan bagian yang tak terpisahkan. Reputasi sekolah tergantung pada reputasi gurunya, keberhasilan siswa tergantung pada bimbingan guru dalam proses pembelajaran. Elias and Arnold menjelaskan "The most significant factors leading to school disaffection, failure, and drop out are social emotional. When teachers leave teaching, it is much more for reasons related to student behaviour, classroom and school climate, and matters of character than it is for anything having to do with technical aspects of teaching an pedagogy" (Elias MJ, Arnold H, 2006:112). Oleh karena itu, maka kecerdasan emosional pada guru akan menjadi panduan yang lebih baik, hal ini merupakan aset terbesar dari sistem pendidikan.

\section{Hakikat dan Pentignya Kecerdasan Emosional Bagi Guru}

Istilah emosi ini sendiri berasal dari bahasa latin, yaitu emovere yang berarti bergerak jauh. Menurut Goleman emosi merujuk pada suatu perasaan dan pikiran yang khas, suatu keadaan biologis dan psikologis dan serangkaian kecenderungan untuk bertindak. Emosi pada dasarnya adalah dorongan untuk bertindak dan biasanya merupakan reaksi terhadap rangsangan dari luar dan dalam diri individu. Sebagai contoh emosi gembira mendorong perubahan suasana hati seseorang, sehingga secara fisiologi terlihat tertawa, 
emosi sedih mendorong seseorang berperilaku menangis (Goleman, D, 1997:411).

Thorndike tahun 1920, meletakkan dasar teori kecerdasan emosional (emotional quotion) pada teori Kecerdasan Sosial (Social Intellegence) yang didefinisikan sebagai kemampuan untuk berprilaku bijaksana dalam berhubungan dengan sesama manusia (Mubayidh, 2010:5). Kecerdasan emosional melibatkan kemampuan merasa secara akurat, menghargai dan mengekspresikan emosi; kemampuan untuk mengakses dan menghasilkan perasaaan ketika mereka memudahkan pikiran; kemampuan untuk memahami emosi dan pengetahuan emosional; dan kemampuan untuk mengatur emosi untuk meningkatkan pertumbuhan emosional dan intelektual. Mortiboys menjelaskan "emotional intelligence means to be able to acknowledge and handle emotions in yourself and in others". Kecerdasan emosional dimaksudkan untuk mendapatkan dan mengelola emosi dalam diri sendiri dan orang lain (Mortiboys, A, 2005:7)

Allport defined an attitude as a mental or neural state of readiness, organized through experience, exerting a directive or dynamic influence on the individual's response to all objects and situations to which it is related (Jeffrey Pickens, 2005:43). Diartikan sebagai satu kesiapan mental atau kecenderungan seseorang untuk melakukan suatu reaksi terhadap objek tertentu yang dipraktekkan dengan cara-cara tertentu pula melalui pengalaman. Jadi emosi merupakan kesiapan mental seseorang yang ekspresikan dalam bentuk sikap yang bisa berupa amarah, kesedihan, rasa takut, kenikmatan, cinta, terkejut, jengkel, dan malu (Jeffrey Pickens, 2005:43).

\section{Pentingnya Kecerdasan Emosional Bagi Guru}

Tidak dapat dipungkiri bahwa, peranan guru dalam pendidikan formal sangat penting. guru merupakan insan yang menanamkan nilai, pemikiran, kestabilan emosi, dan kemandirian fisiologikal siswa, terutama apabila mereka berada dalam lingkungan sekolah. Dampak yang ditinggalkan oleh seorang guru terhadap siswanya sangat mempengaruhi corak pembelajaran dan karir pelajar tersebut 
di masa depan. Oleh karena itu, penting bagi guru untuk menanamkan, mengembangkan, dan melatih kecerdasan emosional pada diri mereka terlebih dahulu, guru harus menyadari akan pentingnya memiliki kecerdasan sosial agar dalam proses pembelajaran nanti guru diharapkan dapat mengambil sikap dan tindakan yang tepat untuk kelancaran proses pembelajaran di kelas. Kecerdasan Emosional di sini berarti kemampuan untuk mempertahankan impuls emosional, untuk membaca perasaan terdalam orang lain dan untuk menangani hubungan dengan lancar. Kemampuan untuk mengendalikan impuls adalah dasar dari karakter (Sreekala Edannur, 2010:115).

Pendidik yang memiliki EQ yang tinggi mampu mengendalikan diri dengan baik, sabar dalam mendidik, tekun, tidak mudah bertindak secara agresif apa lagi sampai mencederakan siswa, serta senantiasa berfikiran positif dalam menjalankan tugas sebagai pendidik, untuk memperoleh EQ yang tinggi individu sepatutnya mendapatkan bimbingan semenjak dari awal lagi, cara yang paling sederhana adalah melalui contoh tauladan yang ditunjukkan oleh ibu bapak di rumah (Hawari, D, 2003:54). Ketika memasuki alam persekolahan, murid dan siswa banyak menghabiskan waktunya di sekolah, untuk itu guru-guru sepatutnya tidak hanya pandai memindahkan ilmu pengetahuan tetapi juga dapat memberikan contoh tauladan yang baik kepada murid-murid dan siswa-siswa mereka (Tajul Ariffin Noordi dan Nor' Aini Dan. 2002:95). Guru memiliki EQ yang tinggi senantiasa dapat mengontrol tingkah laku yang kemungkinan merugikan diri sendiri dan juga orang.

Proses pembelajaran di kelas merupakan suatu interaksi antara guru dengan siswa dan suatu komunikasi timbal balik yang berlangsung dalam suasana edukatif untuk pencapaian tujuan belajar (Pujiastuti Shintya. 2009). Guru dalam proses membelajarkan dituntut untuk professional dalam bersikap dengan membentuk pola interaksi yang dapat mendorong siswa untuk belajar, sedangkan pembentukan sikap yang professional membutuhkan kecerdasan emosi yang dapat mempengaruhi pikiran, perasaan, respon, dan memanipulasi informasi untuk kita 
sendiri dan menjalin hubungan yang harmonis dengan siswa. Sparrow \& Knight menjelaskan bahwa "emotional intelligence integrates feeling, thinking and doing. It is the habitual practice of thinking about feeling and feeling about thinking when choosing what to do". Kecerdasan emosional menggabungkan perasaan pikiran dan tindakan. Ini adalah praktik dari kebiasaan dari pikiran tentang perasaan dan perasaan tentang pikiran ketika memilih untuk bersikap (Sparrow, T. \& Knight, A, 2006:29), karena senyatanya sikap merupakan suatu kesadaran individu yang menentukan perbuatan-perbuatan yang nyata ataupun yang mungkin akan terjadi dalam kegiatankegiatan sosial.

Seorang guru dapat melakukan sesuatu dengan didorong oleh emosi sebagai lokomotor sehingga memunculkan tindakan, mimik, ucapan dan keputusan, entah itu sikap yang merefleksikan sifat negatif maupun positif, dalam arti bagaimana yang bersangkutan dapat menjadi begitu rasional disuatu saat dan menjadi begitu tidak rasional pada saat yang lain. Persepsi guru terhadap siswanya akan mempengaruhi komunikasi yang mereka lakukan. Sebisa mungkin guru tetap menjaga komunikasi yang positif di kelas dan tidak memberikan suatu penghakiman (judgement) bahwa siswa ini cantik, pintar, bodoh, malas, suka membuat gaduh di kelas, dll. Pandangan semacam ini akan membuat guru kurang diperhatikan oleh siswa dan menimbulkan kondisi pembelajaran yang kurang kondusif untuk peningkatan prestasi belajar siswa. Maka, guru harus memandang semua siswa dengan pandangan yang positif agar dari komunikasi yang dibina ini dapat membantu dan memberikan dukungan untuk mengembangkan potensi siswa. Tentu saja tidak setiap guru dalam pembelajaran dapat memberikan respon yang sama terhadap kecenderungan emosinya. Seorang yang mampu mensinergikan potensi intelektual dan potensi emosionalnya berpeluang menjadi manusia-manusia utama. Namun demikian, untuk mendapatkan kecerdasan emosional yang mapan seorang guru harus melakukan latihan yang bersifat telaten dan sungguhsungguh (mujahadah) dengan melibatkan "kekuatan dalam" (inner 
power) manusia sehingga aktifitas kecerdasan emosional menjadi suatu yang mapan di dalam lingkup diri manusia (sub-conciousnes).

Profesi sebagai guru merupakan salah satu profesi yang sangat mulia. Bagaimanapun, professionalisme seorang guru itu tergantung kepada sikap mereka terhadap profesinya yang tercermin melalui tingkah laku kepada siswa. Sebagai pendidik, guru mestilah menjadi contoh yang baik, selalu melakukan rekfleksi terhadap diri sendiri, berdisplin, bersungguh-sungguh dalam mendidik, menepati waktu, berakhlak mulia, dan mempunyai emosi yang stabil. Kepribadian seperti ini dapat memberikan dampak positif dalam pembentukan kepribadian siswa. Hal ini sejalan dengan perintah Allah S.w.t seperti dinyatakan berikut ini; yang artinya "Serulah oleh mu kepada jalan Tuhan-mu dengan bijaksana dan cara yang baik (mau'izah hasanah), serta tegurlah mereka dengan cara yang sesuai" (Qs. al-Nahl: 125).

\section{Kecerdasan Emosional Meningkatkan Daya Kreatif Guru dalam Pembelajaran}

Guru merupakan elemen kunci dalam sistem pendidikan karena guru selalu berinteraksi langsung dengan siswa, memberikan keteladanan, motivasi dan inspirasi secara terus menerus. Oleh karena itu, guru harus selalu bersemangat, berprestasi, dan kreatif dalam berkarya dalam proses pembelajaran. Kaitan kecerdasan emosional dengan kreativitas guru, tergantung pada kondisi dalam lingkungan dan individu itu sendiri. Seseorang yang mempunyai kecerdasan emosional yang baik memiliki daya kreatifitas pribadi yang tinggi, memiliki program kerja berdasarkan rencana dan tujuan yang realistik serta berjuang untuk merealisasikannya, Kreatifitas merupakan perwujudan/pengaktualisasian diri dan perwujudan/aktualisasi diri merupakan kebutuhan pokok pada tingkat tertinggi dalam hidup manusia. Bahkan lebih dari itu bahwa berkreasi dapat bermanfaat bagi diri pribadi, lingkungan, dan juga memberikan kepuasan bagi individu, disamping memungkinkan manusia meningkatkan kualitas hidup khususnya dalam 
menghadapi era pembangunan yang bersifat global (Munandar, Utami, 2009:31).

Bar-on melihat kecerdasan emosional sebagai "an array of personal, emotional, and social competencies and skills that influence one's ability to succeed in coping with environmental demands and pressures". Kecerdasan emosional sebagai sebuah susunan dari personal, emosional dan kompetensi sosial dan kemampuan untuk mempengaruhi kemampuan seseorang untuk sukses dalam membatasi diri dengan tuntutan lingkungan dan tekanan (Pellitteri, J., Tern, R., Shelton, C., 2006:37), kemampuan mempengaruhi, membimbing, mengarahkan dan menunjukkan merupakan daya kreatifitas yang dihasilkan dari kecerdasan emosional. Kecerdasan emosional menggabungkan perasaan pikiran dan tindakan (Sparrow, T. \& Knight, A, 2006:29).

Kreativitas dapat dijelaskan dari sisi product, person, process dan press. Product menekankan pada hasil karya kreatif, baik yang sama sekali atau kombinasi karya-karya sebelumnya yang menghasilkan sesuatu yang baru. Person memandang kreativitas dari segi ciri-ciri individu yang menandai kepribadian orang kreatif berkaitan dengan kreativitas. Process menekankan pada bagaimana proses kreatif itu berlangsung sejak mulai tumbuh sampai dengan berwujud perilaku kreatif. Press menekankan pada pentingnya faktor-faktor yang mendukung timbulnya kreativitas individu.. Prinsip dasar daya cipta/kreativitas sesunggguhnya merupakan perwujudan dari kecerdasan emosional, yang diaktualisasi dalam bentuk kecerdasan intelektual, Emosi dan akal adalah dua bagian dari satu keseluruhan (Ali, 2011:42). Emotional intelegence menggambarkan kecerdasan hati dan Intelectual Intelegence menggambarkan kecerdasan akal/otak. Kecerdasan intelektual dan kecerdasan emosional adalah sumbersumber daya sinergis yang daya cipta/kreatifitas. Wilayah kecerdasan emosional adalah hubungan pribadi dan antar pribadi, kecerdasan emosional bertanggung jawab atas harga diri, kesadaran diri, kepekaan sosial, dan kemampuan adaptasi sosial pribadi (Segal, Jeane, 2000:27). Kreativitas merupakan kemampuan individu untuk berkreasi menciptakan sesuatu baik yang bersifat baru maupun 
yang kombinasi, berbeda, dan unik tergantung pengalaman yang dimiliki. Sedangkan kecerdasan emosional adalah kemampuan untuk menggunakan emosi secara efektif untuk membangun produktivitas dan meraih keberhasilan.

Pembelajaran merupakan suatu proses di mana lingkungan seseorang sengaja dikelola untuk memungkinkan ia turut serta dalam tingkah laku tertentu dalam kondisi-kondisi khusus atau mengahasilkan respons terhadap situasi tertentu, pembelajaran merupakan subset dari pendidikan. Kegiatan pembelajaran adalah merupakan perpaduan antara aktivitas belajar dengan aktivitas mengajar (Sagala, 2003:61), interkasi antara berbagai potensi yang ada dalam diri siswa dengan aneka potensi yang datang dari guru, siswa lainnya, fakta-fakta yang dihadapinya, konsep-konsep yang diketahuinya serta lingkungan yang melandasi proses belajarnya. For successful implementation of creative teaching, the environmental factors that need to be taken into consideration include expectations and interactions as well as teachers' teaching experience and beliefs (Hong, 2003)

Dalam proses pembelajaran, kreatifitas seorag guru adalah hal yang mutlak dibutuhkan, karena kreatifitas merupakan kemampuan untuk menyajikan, membuat dan menghasilkan sesuatu dengan cara yang unik dan menyenangkan, sehingga pesan atau informasi yang di sampaikan dapat diterima dengan baik dan maksimal. Namun jika daya kreatifitas guru tidak selalu dipelihara dengan artian miskin inovasi, kreasi, variasi dan tidak imajinatif dalam membelajarkan, maka kemungkinan besar guru akan kehilangan daya kreativitasnya. Tentunya mandegnya perkembangan daya kreativitas pada guru sangat terkait dengan kecerdasan emosional guru yang belum mapan/matang. Guru lebih banyak melihat pembelajaran dengan cara pandang tradisional, monoton dan tanpa sikap peduli bagaimana pesan itu disampaikan dan bagaimana pesan akan sampai kepada siswa, "Teachers cannot develop the creative abilities of their students if their own creative abilities are undiscovered or suppressed." (Morris, 2006:5) Guru tidak bisa mengembangkan kemampuan kreatif siswa mereka jika kemampuan kreatif mereka sendiri yang belum ditemukan atau ditekan. 


\section{Catatan Akhir}

Pendidik yang memiliki EQ yang tinggi mampu mengendalikan diri dengan baik, sabar dalam mendidik, tekun, tidak mudah bertindak secara agresif apa lagi sampai mencederakan siswa, serta senantiasa berfikiran positif dalam menjalankan tugas sebagai pendidik. guru yang memiliki EQ yang tinggi senantiasa dapat mengontrol tingkah laku yang kemungkinan merugikan diri sendiri dan juga orang lain. Proses pembelajaran di kelas merupakan suatu interaksi antara guru dengan siswa dan suatu komunikasi timbal balik yang berlangsung dalam suasana eduakatif untuk pencapaian tujuan belajar. Guru dalam proses membelajarkan dituntut untuk professional dalam bersikap dan kreatif dalam membentuk pola interaksi yang dapat mendorong siswa untuk belajar, sedangkan pembentukan sikap dan daya kreatifitas membutuhkan kecerdasan emosi yang dapat mempengaruhi pikiran, perasaan, respon, dan memanipulasi informasi untuk kita sendiri dan menjalin hubungan yang harmonis dengan siswa.

\section{Daftar Pustaka}

Ali, Mohammad. Memahami Riset Prilaku dan Sosial. Bandung: Pustaka Cendikia Utama, 2011.

Azwar, S. Sikap Manusia: Teori dan Pengukurannya. Yogyakarta: Pustaka Pelajar, 2002.

Bowkett, S. \& Percival, S. Coaching emotional intelligence in the classroom. New York: Taylor \& Francis, 2011.

Edannur, Sreekala. "Emotional Intelligence of Teacher Educators". International Journal of School of Education, Pondicherry University, Pondicherry, India vol. 2 (2010): 115-121.

Elias MJ, Arnold H. Emotional Intelligence and Academic Achievement.

Social emotional Learning in the Classroom. California: Corwin Press, Thousand oaks: Sage Publications, 2006.

Goleman, D. Kecerdasan emosional, terj. T. Harmaya. New York: Scientific American, inc., 1997. 
Hawari, D. IQ EQ CQ \& SQ: Kriteria Sumber Daya Manusia (Pemimpin) Berkualaitas. Jakarta: Fakultas Kedokteran Universitas Indonesia, 2003.

Hong, Jon-Chao et al. "A Study of Influential Factors for Creative Teaching." http://conference.nie.edu.sg.pdf, diambil tanggal 6 Januari 2014.

Liliweri, Alo. Prasangka dan Konflik (Komunikasi Lintas Budaya dan Masyarakat Multikultural). Yogyakarta: LkiS, 2005.

Morris, Wayne. Creativity Its Place In Education. New Zealand: Future Edge Ltd based in New Plymouth, 2006.

Mortiboys, A. Teaching with emotional intelligence. New York: Taylor \& Francis e-Library, 2005.

Mubayidh, M. Kecerdasan dan Kesehatan Emosional Anak. Bandung: Pustaka Cendikia Utama, 2011.

Munandar, Utami. Mengembangkan Bakat dan Kreativitas Anak Sekolah. Jakarta: Gramedia, 2009.

Noordi, Tajul Ariffin dan Nor' Aini. Pendidikan \& Pembangunan Manusia: Pendidikan Bersepadu. Bangi: As-Syabab Media, 2002.

Pellitteri, J., Tern, R., Shelton, C., et al. Emotionally intelligence school counseling. Mahwah: Lawrence Erlbaum Associates, 2006.

Pickens, Jeffrey. Organizational Behavior and Healt Care. Canada: Jones and Bartlett Publishers, 2005.

Sagala, Saiful. Konsep dan Makna Pembelajaran. Bandung: Alfabeta, 2003.

Segal, Jeane. Melejitkan Kepekaan Emosional. Bandung: Mizan Media Utama, 2000.

Shintya, Pujiastuti. "Pentingnya Pertanyaan dalam Proses Pembelajaran". dalam http:// wmw.sd-binatalenta.com/arsipartikel/ artikel_tya.pdf, diakses tanggal 6 Januari 2014.

Sparrow, T. \& Knight, A. Applied emotional intelligence. West Sussex: Jhon Wiley \& Sons Ltd, 2006.

Yusuf, Syamsu. Psikologi Perkembangan Anak \& Remaja. (Bandung: Remaja Rosda Karya, 2006. 